\title{
Account of Visit to Leprosy Institutions in Nigeria.
}

H. C. Armstrong.

T ARRIVED at Port Harcourt on Sunday, 4th November, 1934, and left on the 4th of December. From Port Har1 court I travelled to Usuakoli and stayed with Dr. Todd until November 16th, and then left for Itu, staying with Dr. Macdonald. During my stay at Uzuakoli I spent a week-end at a new Government settlement at Ossiomo in the Benin Province.

UzUAKOLI.

This settlement is supported from the local native administration funds under the direction of the Primitive Methodists, who supply the Medical Officer.

There are nearly five hundred inmates and the approximate cost per head per year is just over four pounds. No maintenance is paid to the patients, but the settlement 
supplies them with food daily. Most of the food is grown on its farm, and the remainder is obtained from the surrounding farmers at a very cheap rate. The cost per head for the food works out at about 1.4 pence per day.

The settlement is laid out in small two-roomed houses constituted of swish and stick and roofed with grass.

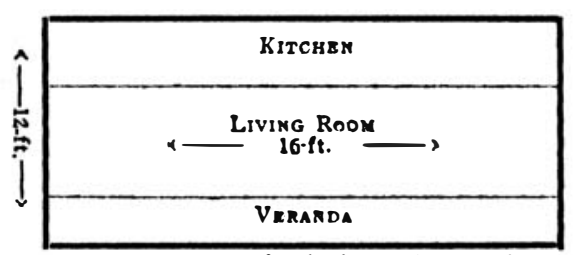

These houses are occupied by 4 patients. The layout of the town is in parallel streets in three groups for male, female and married quarters. The general arrangement has been copied from Itu.

There is no attempt made to segregate different types into different camps, but as far as possible a nodular case would room with a nodular patient in the same stage.

The other buildings consist of (1) Medical Officer's bungalow, servants quarters and stores, (2) Office, (3) Three houses for the non-leprous African staff, (4) "Clean" babies house, (5) Laboratory with stores and dispensary, (6) Hospital with 8 male and 8 female beds, (7) Operating theatre. At the edge of the settlement there is a small dispensary with a hospital of 4 beds for non-leper patients. In the settlement there are sheds for the following occupations :- (1) Carpenters, (2) Black-smiths, (3) Soap makers.

For the social side there is a library, (open twice a week); two churches-Roman Catholic and Primitive Methodists; Scout and Cub headquarters; schools for children during the day and for adults at night.

The healthy staff consists of-two male nurses who also help in the laboratory and non-leper dispensary, one general labourer, and one dispenser.

The leper staff consists of four male temperature clerks, six dressers, four teachers and ten police.

The water supply is from a fresh clear running stream which has been dammed, situated equidistant between the male and female town.

The latrines are in the form of shallow trenches dug daily and covered up after use.

The patients receive weekly injections of the usual antileprotic type. Leprotic reaction cases are admitted at once to hospital. 
ITU.

The settlement at Itu is situated on the Cross River about four miles from the village of Itu. It consists of approximately 1,600 inmates and their houses, similar to those at Usuakoli, and are divided into male, female and married quarters.

The healthy staff comprises the Medical Officer, (Dr. Macdonald) Mrs. Macdonald, a trained nurse who undertakes the usual duties of a hospital matron and also trains the hospital nurses, Mr. Patterson, Inspector of Works and Farm Manager, and Mrs. Patterson, who is Superintendent of the School. There are also two Africans who assist in the office and dispensary.

The leprous executive staff is paid from the funds of the settlement, and consists of twenty police, eleven canoe men, fifty temperature clerks, ten female and eight male nurses, eight gardeners, and four headmen of companies who collect for the poor. There is also one inspector of the poor, three chiefs, one printer, twelve teachers, two engineers for electrical work, six washerwomen, two firewood men, two cooks for hospital patients and two incinerator men.

The rest of the population is engaged in various trades either of a productive or constructive type, also when any member receives an injection he must put in five hours work, e.g. on farms for the settlement in return for his treatment.

The occupations followed by inmates include private store-keepers who buy and sell their produce at the evening markets in the settlement, canoe builders, a blacksmith, an umbrella repairer and a goldsmith. The tailors have their own sewing machines, but if employed by the settlement for making such things as uniforms for police, nurses etc., they are paid 1/6 per day for work done, and 1/- per day for the use of their machine. The settlement also buys the fish caught by the fishermen at market price, less $20 \%$

Only a small percentage own their own farms. The majority are communal, producing yams, cassava, potatoes, corn, beans and ground nut. The cassava is made into a flour called garri, and twenty women are employed at this work. They are engaged on contract and the garri is sold in the market to other patients, or is bought by the settlement, some being used in the hospital for poultices. The communal fiarm also produces lemon grass, women being employed for planting, cutting and steaming the grass. This is collected and placed in a large boiler, steam is passed in at the bottom and escapes at the top, passing into a cooling 
chamber which, after being undisturbed for an hour, contains the lemon-grass oil at the top and water underneath. The water is then run off and the oil is collected. This oil has a market value in England of about 4/- per lb. and cost of production is $1 /$ - per $\mathrm{lb}$. The extraction plant was bought for about $£ 80$ from a scrap iron yard on the Clyde bank.

The palm oil industry employs the greatest number of patients, who are divided into gangs for (a) planting young trees, (b) climbers-for cutting the fruit, (c) transporting the fruit to the extracting sheds, (d) extracting oil. All the work is done by contract and workers receive full market price for oil, less $20 \%$ which goes towards the settlement expenditure. This amount averages just over $1 /$ - per head per week.

Just before leaving Itu it was proposed to plant half an acre of roses and to extract the oil by steam similar to the lemon grass method. The object of this is to provide work for the deformed, who would be able to pick roses. It is not expected that this industry will be on a paying basis.

The building trade employs six men permanently for sawing timber. They are paid so much per plank. There ane also ten "bush" carpenters, who receive about $1 / 6$ for a door and frame and 9d. for a window frame. These articles are sold to the settlement and to any buyer from the surrounding districts. The majority of the houses in the settlement were built by farmers during their off-season. The houses are made from swish, (pise de terre) and stick with a grass roof, and accommodate four people each. This work usually employs 16 men and the time taken is about one week per house. They receive $t 1$ per house.

The settlement also has a small oement block making machine which employs four men. These blocks are sold to the Scottish Mission for building churches, schools, etc.

There are three men employed looking after the herd of goats owned by the settlement. The herd has lately been much improved by importing European he-goats. The milk is used for feeding the babies in the "clean " babies house, and also for patients in the hospital. I formed the opinion that most of Dr. Macdonald's success in dealing with leprotic reactions was dure more to the liberal suppply of clean milk than to any of the medicines commonly used.

There are seven large canoes with expert paddlers. These are hired by Itu traders for transporting cargoes up and down the Cross River. 
During the off season for farming the local District Officer hires gangs of men for drainage and road making. Mr. Patterson, the Inspector of Works, produces odd jobs to be done every day, and so anybody left over from other occupations has some work found for him.

The social and educational side of the settlement is well organised. The school contains 150 children who attend school from 8 a.m. to 11 a.m. and work in the gardens around the European bungalows from $2-4$ p.m. There are night classes for adults, male and female, on alternate evenings, who learn to read and write in their own language. When they ane proficient in reading they are presented with a Bible printed in their own language. This has proved to be a great incentive to learning. The Bibles become their sole property and are given by the Scottish Mission, independently of the leprosy settlement.

The school staff consists of 12 male teachers who undertake the day and evening classes, but when children neach a certain standard, they then help the older people to learn the alphabet, acting as pupil teachers. The school organises a Scout and Girl Guide movement. They meet once a week with occasional field days. Their uniforms are made by the tailors in the settlement. The male children form the nucleus of the settlement's brass band, which meets three evenings a week, and once a week a concert is given. The band plays during Church service and is also employed at the weekly cinema programme given by Mrs. Macdonald.

There are two churches-a small Catholic one and the Church of Scotland which is the chief church of the settlement. This church is built on the side of a hill and seats 1,300 people, having cost only $£ 130$ to build. The seats, altar and pulpit are all made of beaten mud highly polished. The school children constitute the greater part of the choir. From its service collections the church supports eight poor.

The recreational activities include tennis and football. There are four tennis courts made of beaten ant-hill ground up and rolled into the surface. The inmates make their own racquets of solid wood. The Macdonalds give them balls and coach them in the game. There are two grass football grounds. This game is not organised but they can play in the evenings from 4.30 p.m.

Babies born in the settlement are at once removed from their parents to the "clean " babies house. If the mother's condition permits, she comes up to the nursery four times a day. She has to wear a gown with a slit for the breasts and gloves, while the baby is attined in a bag with only the 
head showing. This provides for the minimum amount of contact between mother and child. These children are kept in the clean babies house for three years and if free from all signs of infection they are discharged to their parents' native village and arrangements are made for the relatives to take care of them.

Treatment is carried out twice a week. All patients when coming for their injections bring with them their temperature chart, so that leprotic reactions may be noted at once. The usual standard treatment is for a new case to have, on admission, a course of worm treatment (ol. chenopod : \& carbon tetrachloride) and then a course of quinine. They then receive a three months treatment of avenyl twice weekly, after that, they are given one of the usual antileprotic drugs. At the end of every three months course, they receive another dose of worm mixture. There is a well equipped operating theatre where many major operations are carried out each year. The operation for a radicle cure of hernia appears most popular and also does away with the fear of operations for other conditions. All ulcer cases are regularly explored for necrotic bone.

Latrines ane of the shallow trench type and are dug daily. When I was showing one of the laboratory staff-an inmate-the proper method of examining faeces, I was struck by the number showing ancylostrome eggs.

The water supply is by pipe line to each town. This pipe leads from a tank situated at the highest point in the settlement. It is filled by a hydraulic ram from a fast running stream. Incinerators ane the usual "bush" type, circular in shape and constructed of beaten mud. They are also roofed.

Ossiomo.

This settlement has just been constructed by the Nigerian Government. When I visited there it was in charge of a Medical Officer and a European Sanitary Inspector, who also had been in the Nigerian P.W.D.

The houses were constructed of cement blocks with corrugated iron roofs. The plan was a ground floor block containing $10-12$ rooms, each room to accommodate two patients. There were separate rooms for male and female patients. The other buildings in the settlement included stores, a hospital for twelve patients, an operating theatre, a dispensary and treatment sheds.

There were approximately four hundred patients and most of their time was taken up in bush clearing. So far 
the farms and industries have not been organised. Treatment is similar to that of Itu.

The sanitation is by means of pan latrines, emptied twice daily into Otway fly proof pits. The water supply is from clear streams and springs at the edge of the settlement. Incinerators are constructed of cement blocks of the Horsfel type with drying sheds on either side.

In this settlement there were also large cement baths for administering sulphur baths to patients with scabies and a large disinfector of the Serbian barrel type with downward displacement of steam.

This settlement has now been handed over to three R.C. Mission ladies, two being doctors and one a trained nurse.

When visiting the settlements run by the Missions I was impressed by the attitude of the inmates. The Government settlements compare less favourably with them. This may be due to the mental effect of their different occupations combined with the psychological influence of religious teaching. One must face the fact that the present day specific treatment of leprosy is not entirely satisfactory and it is quite possible that a close analysis of statistics would show that there were quite as many "cures " from non-treatment as from specific treatment. The chief hope for controlling the disease appears to be in efficient segregation of all open cases. This can only be done by having a settlement, which patients are willing to enter at the beginning of their disease and not, as often happens, when they have been driven out from their villages by their countrymen on account of their deformities and foul smelling ulcers. When once in the settlement, their time should be fully occupied with industry and farming in the mornings and afternoons, and in the evenings with mental and recreational activities, so that they have no desire to return to their native village. Marriage should be permitted but care should be taken to remove the infants and bring them up under the best hygienic conditions obtainable. When patients ane engaged in any work they should receive a fair wage, so that they can regard themselves, not as outcasts, but as selfsupporting decent citizens.

The work also increases their bodily resistance to the disease and so increases their hope of a cure. To give a dole or maintenance to able-bodied patients is inadvisable, because the patients refuse to work at farming or any industry except when they wish to fill in a few hours. It 
also destroys morale in the settlement and leaves the Medical Officer without the most important treatment that he can prescribe for the disease and that is healthy out-door exercise.

The original idea at Ho. of giving maintenance so that patients might increase their ordinary diets was excellent, but experience shows that the whole sum is not spent on food. It has oftien been spent on the maintenance of other relatives in outlying villages.

I wish to acknowledge the help and kindness shown to me during my visit to Nigeria by The Honourable Director of Medical Services, Lagos, and Dr. Thomson, the Deputy Director, Medical Service, and the Surgical Specialist at Port Harcourt for arranging my transport and helping me through the Customs. Also Dr. Todd, of Uzuakoli, for accommodating me in his bungalow during my stay at his settlement, and Dr. and Mrs. Macdonald, of Itu, for their numerous acts of kindness and help. I also desire to acknowledge thanks to the Honourable Director of Medical Services, Gold Coast, for permission to undertake these visits to Nigeria.

(Printed by permission of the Director of Medical Services, Gold Coast, and the Director of Medical Services, Nigeria.) 